UDC 658.8:378.1

http://doi.org/10.21272/mmi.2019.1-03

JEL Classification: A22, A23, H52

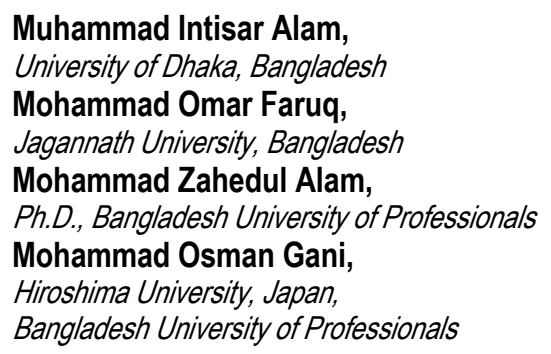

\title{
BRANDING INITIATIVES IN HIGHER EDUCATIONAL INSTITUTIONS: CURRENT ISSUES AND RESEARCH AGENDA
}

\begin{abstract}
Branding is a very common issue for Higher Educational Institutions like other profitable organizations over the last few years. This study illustrates the present branding scenarios of different public and private universities of Bangladesh which will help to provide a vivid knowledge about the regional universities of Bangladesh. Addressing to the present branding challenges and issues, it was observed that the process of branding initiative is very complex due to multiple reasons, i.e. lack of consistency, accuracy, and commitment from the different stakeholders. For the purpose of the study, the top ten leading public and private universities have been selected for collecting data on brand initiatives. For the objective of the research, 200 existing students along with 200 potential students were selected. Students, qualified or eligible for university admission were taken randomly as the sample of the study. Several variables including images of the university, education quality, rank, reputation, location, political situation or influence and teachers' quality have been measured through a seven-point measurement scale to evaluate the branding initiative. This study reveals that regarding the selection of the public and private universities in Bangladesh, students have a wide range of consideration; and their evaluation about the institution is in paradox, because the institutions they have intended to attend may not be going to fulfil their desired expectations in terms of different dimensions. Branding initiatives of the selected universities are not enough in these circumstances for branding Bangladeshi universities at an international level. Findings of the study have revealed that students are going to target the branded and reputed universities comparing to the quality of education. It has also been observed that employers also recruit graduates from the top-ranking branded universities for their organizational performance. The academics and the marketing policy makers of public and private universities will be assisted by the findings of this study regarding their branding issues in future. Lastly, the study highlights some limitations and future direction in this context.
\end{abstract}

Keywords: branding, Higher Educational Institutions, marketing, Bangladesh, student.

Introduction. To get a better nation, higher educational institutions are undoubtedly needed. To fulfil the educational and knowledge spreading need, universities were established all over the world. Similarly, there is a recorded number of public and private universities have been established in Bangladesh. According to the University Grant Commission (UGC, 2017), there are 42 public and 96 private universities in Bangladesh. It is a matter of sorrow that, not a single university could keep the place in the world ranking position. Apart from this, numbers of universities all over the world continuously trying to build their reputation to create it as a centre of attention. Only because of better positioning, branding has become more important for universities in the marketplace. Getting degrees from these «branded» institutions are more likely to gain something worthy and from that consequence's employers are accepting the students having good brand value. Students and employers are more likely to recognize the «name» of the institution in an environment in which the names of units, courses, and granted degrees are easily distinguishable from other institutions. Effective marketing and branding initiatives are crucial for survival in this industry. Importance of these activities is increasing continuously as the universities are looking to

Cite as: Alam, M. I, Faruq, M. O., Alam, M. Z., \& Gani, M. O. (2019). Branding Initiatives in Higher Educational Institutions: Current Issues and Research Agenda. Marketing and Management of Innovations, 1, 34-45. http://doi.org/10.21272/mmi.2019.1-03 

Research Agenda

appeal to an ever-increasing and diversified student base. Effective branding can increase enrollment, the ability to raise funds and other outcomes. Many educational institutions across the world create an image to attract best students, best faculties, researchers and staffs; this process is called branding. Branding began as a channel of choice for consumers and has grown to include what an organization represents in worth and values. For developing a brand some «points of differentiation» (POD) and some «points of parity» (POP) is needed. These two branding concepts have been used to establish and communicate the essence of technical \& professional degree programs among stakeholders - candidates, students, parents, alumni, employers, community, etc. Hardcore marketing (selling included) concepts are used for such institutional level branding.

The branding notion of academic institutions differs from the commercial sector. Institutional branding is related to the institutions' academic prestige, which is a purpose of the desired brand image, brand attributes, and brand benefits. Moreover, institutional branding drives an institution from its mission to its vision by sustaining the powerful marketing strategy that helps to achieve the goals. Branding an institute is a two-pronged holistic exercise; first brand construction by making \& fulfilling unique commitments, and subsequent brand promotion. Corporations commonly implement branding initiatives through trademarklicensing programs due to competition and infringements that mocked their services or marks. Specifically, corporations across the world wanted to be unique from others that might have similar offerings. This study examined the importance and perceived impact of branding initiatives in higher educational institutions in Bangladesh. Higher educational institutions are facing a huge stake in the quality and type of students they are going to attract, as the composition of their students' group is critical to their development and success. Prospective degree candidates view the university as a serving system which will act for teaching them, placing them in careers and graduate schools, and providing a lifelong community. An institution's ability to raise its standing point depends on attracting top faculty, developing new programs, and bringing in top recruiters. Increasing university's endowment, expanding in size and scope, and staying engaged with the world all depends on students and alumni who are both ambassadors and supporters of the school. A recent study by communications agency Noir Sur Blanc revealed that about $93 \%$ of administrators in higher education had already acknowledged their institution as a brand. During the last decade, technology, globalization, and competition have caused the ground to shift under higher education worldwide. In this continuously evolving marketplace, university branding is not just about logos. Sound key values stand for the institution such as academic integrity; chances of employability later; and most importantly the value of the student experience should be created and communicated by them. Question is there, to whom it will communicate? Nowadays both students and parents are treated as a value receiver for the educational institution from the perspective of Bangladesh. So, the university needs to communicate to the actual and potential students, their parents, to the different corporate houses and other stakeholders. This research will find out what will be the different strategies to build brand equity of universities to different stakeholders. Students are attracted to a university by a number of issues: a) as a brand which is historically recognized based on how long it takes to found that university; b) fascinating campuses located at a good sites with luxurious grass-filled and modern or historical buildings that prides upon up-to-date facilities; c) teachers and researchers who are acknowledged worldwide as well as recognized products attributable to the faculty member or university, and d) perception of public that the young match best with giant and reputable universities for education. With this backdrop, it is essential to examine the branding initiatives of higher education institutions and their current issues and give directions for further research. The main purpose of this research is to investigate the literature review regarding the branding initiatives in higher educational institutions, how branding initiatives can work in higher education, examining the necessity of branding in higher education of Bangladesh, and identifying the challenges of branding the universities. 

Research Agenda

Review of Literature. Very few articles have been found regarding the branding initiatives of universities. Brands provide a great deal of value to consumers and perform the following functions for marketers: (1) identification of the source of the product, (2) assignment of responsibility to product maker, (3) risk reducer, (4) search cost reducer, (5) promise, bond, or pact with maker of product, (6) symbolic device, and (7) signal of quality (Keller 2003). According to Coleman (2010), the American Marketing Association (AMA) first produced a brand definition in the 1960s that brand implies a name, term, mark, symbol, design or a mixture of all of these, aimed to both detect the goods or services of one vendor or a group and differentiate them from the goods or services of competitors. Mathew (et al., 2012) research used survey data gathered at two universities in the United States has stated the criteria that public and private universities student might use while choosing the colleges/universities for applying. Mathew Joseph (et al., 2009) findings lend support for university branding initiatives that seek to promote the university experience as including amenities, updated facilities, and programs that appeal to the modern student. Many universities have picked marketing specialists from the corporate world and invested valuable time and financial resources to build powerful institutional brands. In some cases, such as at Northwestern University in the US, they have created Chief Marketing Officer (CMO) positions and made brand development and marketing campaigns a core function of the institution (Morrison M, 2013). According to Shampeny (2003), «With the increasing cost of university tuition, the competition for students, and in the case of state colleges and universities, decreasing state funding, colleges are continually looking for ways to attract students, fund their mission and stand out from the crowd» (Chapleo, 2005). Branding in universities is a periodic issue, but some UK universities have fully created "successful" brands like commercial organizations. Most notably, branding in higher education is about who they are and is not confined to what a product offers the marketplace. An educational brand is highly associated with an institution's academic prestige. Nevertheless, that statement can be considered far too limiting. A college or university brand is associated with the institution's personality-congruent with its mission, described by its values (Jim Black, 2008). Every university should have a documented positioning statement and brand strategy. Faculty members and staff should be intimately involved in developing a university's brand strategy (Elizabeth Scarborough, 2007). Universities are finally recognizing that name recognition, image, and positioning (all elements of a brand) exert strong influences on students as they decide which university to attend and on donors as they decide which university to support everything depends on the corporate brand image of the universities. Now more than ever, branding has become an emerging imperative for colleges and universities (Robert A. Sevier, 2000). An institution's brand is shaped by the sum total of the expectations and promises it sets among a targeted set of constituents - and by how well it delivers on those promises. Institutions need to reaffirm their mission, vision and values, a process that finds the common ground across sometimes divergent views of a) the founding mission of the institution b) evolving vision of how that mission can be fulfilled in a changing world and c) values that define the institution and form an important foundation on which key promises are built (Kathleen Dawley, 2000). The improvement of higher education facilities may attract foreign students to our country as well as local outgoing students who could generate more government revenues (Bhuiyan and Hakim, 1995). The quality of education depends on quality classroom teaching also (Rony and Rashid, 2009). Standard of quality teaching depends on:

- clear tasks/aims;

- competence of the teacher;

- use of suitable teaching methods;

- meaningful outcome of teaching;

- effective presentation of scientific knowledge;

- teacher's self-assessment (Ronny and Rashid, 2009). 

Research Agenda

Creating a powerful brand is a vital element of the marketing strategy of colleges and universities whose sustainability is highly dependent on external stakeholders. University brand managers could be benefited by creating a greater understanding of the customer's interaction with their brand which is important for developing good effective recruiting material, promotions, and other marketing activities, etc. The current research uses the concept of brand personality to university academic and athletic logos and studies subsequent connections among perceived brand personalities. An online study result revealed that competence is a brand personality dimension often linked with academic logos, and excitement is the brand personality dimension often linked with athletic (Brandi A. Watkins, 2013). Black (2008), President and CEO of SEM Works, explained that branding corporations have unquestionable parallels to implement branding in higher education. Lockwood and Hadd (2008) stated similar to corporations, higher education institutions serve diverse audiences and there is a price behind the educational experience: institutional sustainability is largely reliant upon the income earned from student enrollments; they have competitors; compete on price, quality, service, and reputation; their image is largely determined by the constituents they serve; and the image of their institutions is influenced by their interactions with students (Black, 2008). The significance of branding in educational institutions has been indicated by Kotler and Fox (1995) who said that an educational institution's offer could be added value and provided more satisfaction for the customers by branding. However, there are still limitations in published literature related to branding in an educational institution. Discussion of marketing literature in HEls has been originated since the early 1980 s asserted by Rosenthal (2003), the branding process and the change process are two noteworthy extents within the educational institutions' settings. Rosenthal (2003) indicated that branding is particularly important to higher education, «as there is a high degree of overlap among competitors» offerings, with comparable pricing among categories of institutions. The brand itself is therefore particularly important to successfully marketing an academic institution". Higher education is comparable to businesses and would benefit if viewed from a corporate lens to focus on the unique attribute an institution provides, while potentially increasing the interest of prospective students and enrollment. «Think of a college or university brand as being synonymous with the institution's personality-congruent with its mission, defined by its values» (Black, 2008).

Similarly, to corporations, it is important for higher education institutions, like corporations, to emphasize their matchless elements to the greater community. Waeraas and Solbakk (2009) stated, «To our knowledge, no one has adopted an internal focus by investigating exactly how branding efforts unfold in specific cases and what happens during these processes». Although there is limited research in branding in higher education, the authors also believed that the topic should be researched further in order to define the «university brand». Waeraas and Solbakk (2009) stated that there is increasing the importance of branding in academia, but very few papers are exposed by literature searchers that precisely address higher education branding. While some of the university selection criteria examined appear to remain consistently important over decades of research, amenities/facilities emerged as an important selection factor in this study and would seem to reflect a 21 st-century view of the university experience. Though some within the academic community have raised sharp criticism of the lengths to which colleges and universities are going to distinguish themselves from competitors by building elaborate recreation centres, student centres, and student housing (Twitchell, 2004). Our findings suggest that these amenities may be very important to the modern student when choosing among higher education alternatives. Lastly, given the branding implications of these findings, recommendations and suggestions were made for marketing managers and higher education administrators regarding marketing messages that may have the greatest impact on prospective freshmen.

Like many service-oriented organizations, universities are facing an increasingly competitive environment in which they must find ways to differentiate their institution and tell their story. Various technological and social changes continue to erode the monopoly that universities once had over 

Research Agenda

intellectual resources and privileges (Burbules and Callister, 2000). When addressing new challenges, the higher education paradigm must be continually re-engineered from the ground up to facilitate an entrepreneurial spirit and a coordinated, customer-driven strategy (Dimun, 1998). Universities have increasingly implemented integrated marketing techniques to strengthen promotional efforts (Wasmer, Williams, and Stevenson, 1997). As part of institutional efforts toward a coordinated, customer-oriented marketing system, universities must also include a focus on developing the university brand. Within the university setting, «a brand is a name, an image, a compelling description of an organization that captures the essence of the value that your college provides» (Frederick, et al., 2000). The usefulness of this brand is that it allows individuals to decide on a limited amount of information (Papp, 2002). Selecting a university to attend is certainly a complex consumer decision and looking to the brand simplifies the selection process for many. Thus, universities have increasingly recognized the importance of developing a brand identity for the university. According to Lawlor (1998) brand identity is «the essence of how you would like alumni, prospective students, legislators, and the public to perceive your institution». The University of Houston recently decided to take a proactive approach and implemented a five-year, $\$ 5$ million image campaign (Hacker, 2005). Likewise, Point Park University in Pittsburg unveiled a \$1 million branding campaign via billboards, print ads, and other media (Schackner, 2004). When evaluating a complex intangible offering, consumers will look not only to the brand but also to people within the organization for clues. According to Sevier (1994), university students generally offer four reasons for their school choice: (a) image or reputation, (b) location, (c) cost, and (d) the availability of a major. When asked to choose among the four factors, students invariably choose an image. Berger and Wallingford (1996) apply the hierarchy of communication goals, widely used in consumer advertising, to the field of higher education and investigate the university selection process undertaken by prospective students. They concluded that «reputation» and "academics» were the two most important factors in selecting a school to attend, with "cost» and «location» following closely behind (Berger and Wallingford, 2003). The marketing budget at an academic institution typically accounts for less than one per cent of the total university budget (Lipman Hearn, 2001). In addition, 14 per cent of public institutions faced budget reductions in recent years (Lipman Hearn, 2001) and many universities are currently bracing for further cuts. For organizations within the services sector that face the challenges of developing the brand for an intangible and complex offering in a cost-effective manner, developing the brand from the inside out can be a powerful strategy. From the above discussion, it has been observed that Universities should take some branding initiatives to build strength in the minds of people. Since the brand is the sum of all associations with the university in the target people. An initiative should be taken to build a brand in the minds of target people which reflect all associations of a University.

Research Questions:

RQ1. How are brands built and managed in Higher Educational Institutions?

RQ2. To what extent do educational institutes" resources and capabilities, structures, and processes advance or mitigate brand-building among educational institutions?

RQ3. To what extent do brand identities (name, logos, signage, URLs, packaging, symbols, characters, spokespersons, slogans and jingles) affect corporate branding in higher educational institutions" settings?

RQ4. Is branding needed for higher education to keep positioning and attract foreign/local students?

Methodology. The study used a systematic review for this study as opposed to the traditional literature review. The systematic review approach enabled the authors to ensure broader literature coverage with high transparency, reproducibility and methodological rigour (Cook, 1997; Tranfield et al., 2003). The approach also ensured the provision of valuable insights for future research (McKibbon, 2006; Keranen et al., 2012). The research method for this review has been discussed in the following section. The study is qualitative in nature. For the study, data have been collected from both secondary and primary sources. However, maximum concentration was given on secondary sources of data. All the primary data were 

Research Agenda

collected from a personal interview with existing students, potential students from some selected public and private universities in Bangladesh. 200 existing students and 200 potential students who are qualified or eligible for university admission were selected for the study. Simple random sampling technique has been used to take this sample size. The study period is from June 2013 to 1 July 2017. Four items were used to determine the respective university brand strength among university administrators based on their perceptions of the distinctiveness of their university's brand, the clarity of their university's internal branding message, the degree of university involvement in the promotion of the brand, and their university's brand image as compared to that of prospective students' perception.

Brand management may be more difficult for universities than the corporate world. Several developments have been observed in recent years that have significantly complex marketing exercises and creates hurdles for brand managers in any organizations whether it is profitable or not for profit organizations. There are some challenges for brand builders that have been emerged in the twenty-first century because of technological advancement, rapid globalization and severe competitive environment i.e. savvy clients, more complicated brand families and portfolio, evolving markets, more complex and growing contest, difficulty in distinguishing, lowering brand loyalty in many levels, increase of private label, growing trade power, fragmenting media coverage, changes in media attitude, eroding traditional media effectiveness, rising newly communications alternatives, rising promotional expenses, decreasing advertising expenses, the rising cost of product introduction and support, short-term performance orientation and growing job turnover etc.

Results. There are about 138 universities in Bangladesh from those 42 universities are in public sectors and 96 in private sectors, 32 universities give general classroom education facilities and services. Bangladesh Open University (BOU) carries non-campus distance education programmes. Bangladesh National University normally operates as an affiliating university for degree and post-graduate degree level education at various colleges and institutions in the various field of education. Dhaka University is one of the pioneering universities in Bangladesh. After the liberation of Bangladesh in 1971, during the last 44 years, the higher education scenario has greatly been transformed. The number of public universities has increased significantly due to the governmental initiative. Public universities are the foremost choice of many students seeking higher education. This is for various reasons. First, these universities offer a wide range of subjects in Science, Commerce, Liberal Arts, Humanities, Engineering and Technology, Law, Education and Medicine disciplines. Second, public universities attract the best brains and researchers as teachers although monetary compensation for them is anything far from attractive. Third, library, laboratory, internet, and research facilities are much better there than anywhere else in the country. Fourth, seminars, symposiums, workshops, debates, exhibitions and visiting teachers lecture series are often held in these institutions with a wide scope for national and international exposures for promising young knowledge seekers. Fifth, residential and boarding facilities at low cost/subsidized rates are available in these public universities. The spectacular growth and expansion of private universities in Bangladesh are remarkable. The North South University (NSU), was the first private varsity in Bangladesh which was approved by the government of Bangladesh on 5 November. 1992 (Alam et, al., 2007). The government in power at that time (1991-1996) showed a positive attitude towards opening the opportunity for more private universities in Bangladesh and from 1991 to 1996, sixteen private universities (mostly in metropolitan Dhaka, with only two in Chittagong) were established (Alam et, al., 2007). During 1996-2001, the government was not very favourable toward the concept of the private sector of education. Only four new universities were added to the list during 1996-2001 and after 2001, the private university concept got a significant boost again.

In Bangladesh at present, there are 112 universities (34 in the public sector and 78 in the private sector) which grant diplomas in a specific field as well as bachelors and higher degrees. The expansion of Bangladeshi higher education in recent years has largely been due to the rapid growth and development 

Research Agenda

of private universities. Establishment of a private university in Bangladesh initiated after the institution of the private University Act 1992. The main features of Branded world ranking Universities are the followings; Technology and Higher education, online education, Recruitment of International Students, Research and Development (R\&D), Recruitment of diverse faculty members, etc.

There are many challenges faced by the public university in Bangladesh. Corruption is one of the barriers to higher education. Besides, nepotism, recruitment of less meritorious teacher by political identities have created an obstacle in higher education. Nevertheless, financial crisis, lack of residential halls, shortage of seats for the applicants as well as the involvement of teachers with other activities have also been identified by the respondents as the barriers of quality education in Bangladesh.

The traditional teaching method is a common feature in our universities. Here, the sharing of knowledge and students' participation is very minimal. The brainstorming discussions and presentations by the students enable them for better grooming up. However, this is almost absent in our university education system. Moreover, the monologue type of teaching and learning, the traditional system of distant relationship between teachers and students act as barriers in the congenial atmosphere of free learning in the universities of Bangladesh. Simultaneously, modern teaching methods and facilities like internet, multimedia, sound system are also being absent at the public university of Bangladesh. Poor quality of teaching staffs who fail to satisfy the students' needs both in quality and quantity. Most of them have a lack of specialized research and training on higher education. Moreover, due to the recruitment of political consideration, a good number of teachers have no scientific and update knowledge that assists them to change their teaching methods.

Table 1. The Main Features of Branded Public and Private Universities in Bangladesh

\begin{tabular}{|c|c|}
\hline Public Universities & Reasons behind Branding Universities \\
\hline University of Dhaka & $\begin{array}{l}\text { Linkage to the history of Bangladesh and first public university in Bangladesh and } \\
\text { location at capital city }\end{array}$ \\
\hline IBA & Linkage with the corporate world \& Good quality intake \\
\hline BUET & Research in Engineering and Achievements of International recognition \\
\hline Jahangirnagor University & Natural Beautification and Historical name \\
\hline University of Chittagong & $\begin{array}{l}\text { Only one public university in Chittagong division. Name of the port city and natural } \\
\text { beauty in the campus }\end{array}$ \\
\hline University of Rajshahi & Largest campus and only one university in North Bengal. \\
\hline Private Universities & \\
\hline North South University & $\begin{array}{l}\text { First Private University in Bangladesh and Modern facilities and Club activities in the } \\
\text { campus }\end{array}$ \\
\hline Brac University & NGO affiliation and focus on a national and international seminar at the campus \\
\hline East-West University & Quality education, Modern facilities, and Permanent campus with modern facilities. \\
\hline Independent University & Permanent Campus with modern facilities and Rich library facilities \\
\hline
\end{tabular}

Sources: compiled by the authors.

The result of potential students' consideration based on Intrinsic and Extrinsic attributes for choosing a public university. Consideration of choosing public universities is shown in Table 2.

Table 2 reveals that all the respondents consider seven attributes which offer on potential student mind for choosing a public university. The brand image of the university has got the highest importance, the weighted average being 2.65 for the attributes. The next important attributes are:

- quality education (2.40);

- $\quad$ rank (weighted average being 2.35);

- reputation (weighted average being 2.25 );

- excellent teachers' quality (weighted average being 1.00); 
M. I. Alam, M. O. Faruq, M. Z. Alam, M. O. Gani. Branding Initiatives in Higher Educational Institutions: Current Issues and Research Agenda

- politics-free and session jam free (weighted average being .80)

- location (weighted average is 0.35 ).

Hence it is of no importance to the respondents while considering by subscribers for choosing the university.

Table 2. Consideration for choosing a public university

\begin{tabular}{|c|c|c|c|c|c|c|c|c|c|}
\hline \multirow[b]{2}{*}{ Attributes } & \multicolumn{9}{|c|}{ Responses } \\
\hline & 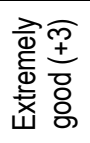 & 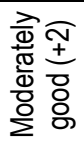 & 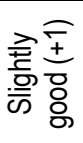 & 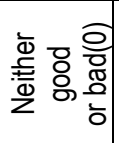 & 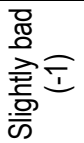 & 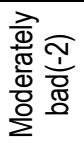 & 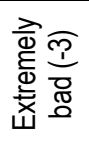 & 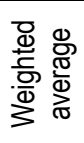 & 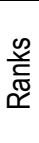 \\
\hline Brand Image & 150 & 30 & 20 & 0 & 0 & 0 & 0 & 2.65 & 1 \\
\hline Quality & 120 & 40 & 40 & 0 & 0 & 0 & 0 & 2.40 & 2 \\
\hline Rank & 130 & 30 & 20 & 20 & 0 & 0 & 0 & 2.35 & 3 \\
\hline Reputation & 100 & 50 & 50 & 0 & 0 & 0 & 0 & 2.25 & 4 \\
\hline Location & 20 & 30 & 50 & 30 & 40 & 30 & 0 & 0.35 & 7 \\
\hline $\begin{array}{c}\text { Politics and Session Jam- } \\
\text { free }\end{array}$ & 40 & 30 & 50 & 40 & 20 & 10 & 10 & 0.80 & 6 \\
\hline Teachers' quality & 40 & 40 & 40 & 40 & 40 & 0 & 0 & 1.00 & 5 \\
\hline
\end{tabular}

Note: Weighted Average is calculated given weight -3 for extremely bad to +3 for extremely well. Weighted average $=$ Column times row divided by the total number of Respondents.

Sources: Field survey, 2018

Among the universities, potential students are asked to mention the best University, $72 \%$ of the respondents mentioned the name of Dhaka University which is the top-ranking university in Bangladesh and then BUET which is top ranking Engineering University in Bangladesh. The analysis hypothesis:

$\mathrm{H}_{\mathrm{o}}$ : Students are not influenced to choose a University for a unique curriculum, a variety of courses and employability.

$\mathrm{H}_{\mathrm{A}}$ : Students are influenced to choose a University for a unique curriculum, a variety of courses and employability.

Similarly, $Z$ cal $=14.47$, at $5 \%$ level of significance, follows $Z$ distribution $Z_{0.05}=1.645$.

Since $Z_{\text {cal }}>Z_{\text {tab }}$, the null hypothesis is not acceptable. So, at $5 \%$ level of significance, it can be said that Students are influenced to choose a University for a unique curriculum, a variety of courses and employability.

$\mathrm{H}_{\mathrm{o}}$ : Tuitions fee is not a great concern to select a University for higher education.

$\mathrm{H}_{\mathrm{A}}$ : Tuitions fee is a great concern to select a University for higher education.

Similarly, $Z c a l=6.41$, at $5 \%$ level of significance, follows $Z$ distribution $Z_{0.05}=1.645$.

Since $Z_{\text {cal }}>Z_{\text {tab }}$, the null hypothesis is not acceptable. So, at $5 \%$ level of significance, it can be said that Tuitions fee is a great concern to select a University for higher education.

$\mathrm{H}_{\mathrm{o}}$ : Physical evidence like campus facilities, the uniqueness of campus, external ambience and landscape, facilities cannot draw more interest to the students.

$\mathrm{H}_{\mathrm{A}}$ : Physical evidence like campus facilities, the uniqueness of campus, external ambience and landscape, facilities can draw more interest to the students.

Similarly, $Z$ cal $=8.68$, at $5 \%$ level of significance, follows $Z$ distribution $Z_{0.05}=1.645$. 
M. I. Alam, M. O. Faruq, M. Z. Alam, M. O. Gani. Branding Initiatives in Higher Educational Institutions: Current Issues and Research Agenda

Since $Z_{\text {cal }}>Z_{\text {tab }}$, the null hypothesis is not acceptable. So, at $5 \%$ level of significance, it can be said Physical evidence like campus facilities, the uniqueness of campus, external ambience and landscape, facilities can draw more interest to the students.

$\mathrm{H}_{\mathrm{O}}$ : Branding Universities do not give a competitive advantage in the marketplace.

$\mathrm{H}_{\mathrm{A}}$ : Branding Universities give a competitive advantage in the marketplace.

Similarly, Zcal $=6.44$, at $5 \%$ level of significance, follows $Z$ distribution $Z_{0.05}=1.645$.

Since $Z_{\text {cal }}>Z_{\text {tab }}$, the null hypothesis is not acceptable. So, at $5 \%$ level of significance, it can be said that Branding Universities give a competitive advantage in the marketplace

$\mathrm{H}_{\mathrm{O}}$ : Lack of Branding Initiatives do not keep down the University Ranking in Present age.

$\mathrm{H}_{\mathrm{A}}$ : Lack of Branding Initiatives keep down the University Ranking in Present age.

Similarly, $Z$ cal $=5.11$, at $5 \%$ level of significance, follows $Z$ distribution $Z_{0.05}=1.645$.

Since $Z_{\text {cal }}>Z_{\text {tab }}$, the null hypothesis is not acceptable. So, at $5 \%$ level of significance, it can be said that Lack of Branding Initiatives keep down the University Ranking in Present age

$\mathrm{H}_{\mathrm{O}}$ : Top Universities do not hold their position in the top because of the excellent Branding policy.

$\mathrm{H}_{\mathrm{A}}$ : Top Universities hold their position in the top because of excellent Branding policy.

Similarly, $Z$ cal $=12.13$, at $5 \%$ level of significance, follows $Z$ distribution $Z_{0.05}=1.645$.

Since $Z_{\text {cal }}>Z_{\text {tab }}$, the null hypothesis is not acceptable. So, at $5 \%$ level of significance, it can be said that - Top Universities hold their position in the top because of excellent Branding policy.

Here, the synopsis of the research has been narrated. Today, it is the age of trade and commerce. The success of an organization depends on branding activities. The success of branding depends on creativity. The first goal of this research is to examine the existing branding activities of selected universities in Bangladesh. Some selected issues have been discussed to fulfil this objective. The researcher has tried to show the existing branding programs of selected universities. It has been seen that the maximum of the existing branding activities is very poor. This university spends a small amount of money on branding activities. This university uses various types of platforms for branding. In this study, top branded foreign, local including branded public and private universities have been studied. It has been observed that most of the foreign universities have excellent research facilities and high-profile novel laureate faculty members. These universities have years of experiences, the opportunity of the country of origin. Most of the foreign universities have collegiate universities; there are many affiliated colleges. These universities focus on research and development and get a donation from the state and donor agencies for research and development.

Top 10 local universities have been studied regarding branding; it has been observed that most of the private universities have a lot of club activities for branding. They always focus on club activities and collaboration with the corporate organization. These universities always focus on modern classroom facilities and high-profile teachers with a foreign degree. Top public universities have been studied; it has been observed that most of the public university have years of experiences, the largest campus and names are associated with district name. At Dhaka University, there are many departments and faculties which are very helpful for branding. Dhaka University has a linkage with the history of the country; this university arranges different national program which creates a crowd of the mass public. 

Research Agenda

Conclusion. Universities should take the necessary steps to create awareness among the general people through mass media coverage. They should promote the brand initials like MIT, RMIT or UCLA, etc. Universities need to create one unified message based on what makes their university different, who they are, and what they do. They should remove the misconception regarding public or private university as soon as possible. They need to focus on public relations not advertising that creates a sense of belonging through engagement. They need to organize some rally for massive events every year to brand itself. These events can be backed up by prominent and renowned sponsors. In its annual campaign, they should organize an event in which universities should focus on the core value of the universities. They should target students in both urban and rural area like other public universities, but the social class has to be middle to higher class since the cost of education is higher than typical public universities. Corporate identity should be increased through an integrated communication program for BUP branding. High profile faculty members should be recruited as soon as possible. In some cases, BUP needs to provide some support and evidence to convince the high-profile faculty members. For University branding, the entire university community-alumni, faculty, students and their families, staff, elected officials must focus on this common purpose. Moreover, to do so, they must embrace a new framework for how they think about and communicate about the university. They should focus on discipline, punctuality and good faculty members and they should maintain the strictness in complying rules and regulations of the University. Interaction with other university and community should be increased. Universities should increase co-curricular activities among students. The faculty member should be given more flexibility in their activities and independence.

They should increase connection with more media and public and should arrange national and international seminar, workshop, and conference on the campus. They can organize an exchange program with other public and foreign universities. Universities should arrange some programs where directly involve the outside students and parents. The university authority should monitor properly to add new and innovative courses and ideas in the learning process so that the students can face the challenges of the new millennium. Higher education should be highly participatory, reciprocal and research-based. Both teachers and students spontaneously participate in this learning process and research activities. Universities should provide higher education according to the need-based. Simultaneously unnecessary, self or specific group interest related initiatives should be discouraged. Moreover, new institutes should be opened aiming at reducing regional imbalances and resource mobilization. The quality of education in any university depends directly upon the quality of the teachers and condition of appointment. Thus, only those with the best academic records should be appointed on attractive conditions as teachers. The quality of education in any university depends upon the academic performances of the students seeking admission. So, endeavour should be made for taking superior quality students. Universities may put the bar on students using coaching centres. The superior curriculum of courses is important, but more important is the method of execution. The universities generally prepare good quality curriculum, but endeavour should be made to monitor how those are being executed. University should empower and support individual departments to implement the designed program. To attract public attention and keep it engaged with an organization or an individual, Universities can take advantage of every public event and the opportunity to speak publicly.

It is proved that «Branding is needed for higher education to keep positioning and attract foreign/local students' In case of an institution» internal factors, they need to think about the key staff members who should be specialized in certain areas as well should be pitched to the media as a spokesperson. Universities can promote its key staffs, faculties and outstanding students in national media. Universities also need to build a brand promise based on academic offerings, student experience, and an institution's prestige. From this study, it has been observed that research and development is the main instrument for 
M. I. Alam, M. O. Faruq, M. Z. Alam, M. O. Gani. Branding Initiatives in Higher Educational Institutions: Current Issues and Research Agenda

promoting the universities in the national and international arena. Thus, universities should concentrate on research and development of their faculty members and their associations.

Authors Contributions: Authors have an equal contribution for preparing the manuscript. For the conceptualization A. M. Z. and G. M. O., methodological issue by A. M. Z., software A. M. Z. and G. M. O. analysis and investigation G. M. O., A. M. I., A. M. Z. F. M. O., resources G. M. O., writing and original draft - G. M. O., A. M. I., revision - A. M. I., F. M. O., formatting - G. M. O.

\section{References}

Aaker, D., A. \& Joachimsthaler, E. (2000). Brand Leadership, New York, the Free.

Aaker, D., A. (2004), Leveraging the Corporate Brand, California Management Review, 4, 6-18.

Alessandri, S., W. (2001), Modeling Corporate Identity: A Concept Explication and Theoretical Explanation. Corporate Communications: An International Journal, 6, 173-182.

Bangladesh University Grants Commission (2006). Strategic Plan for Higher Education in Bangladesh: 2006-2026, Dhaka.

Bangladesh University Grants Commission (2010). Annual Report-2010

Bangladesh University Grants Commission (2011). Annual Report-2011

Black, D. J. (2008). The Branding of Higher Education. Greensboro, NC: SEM Works

Bonnema, J., \& Van der Waldt, D. R. (2008). Information and Source Preferences of a Student Market High Education. International Journal of Educational Management, 22, 314-327.

Brandi A. Watkins ET. el., (2013), «Assessing University Brand Personality through Logos: An Analysis of the Use of Academics and Athletics in University Branding». Published Online: 16 July 2013.

Chris Chapleo (2005) Do Universities Have "Successful" Brands? International Journal of Educational Advancement, 54-64; doi:10.1057/ Palgrave. ijea.2140233, University of Portsmouth, Richmond Building, Portland Street, UK.

Donald, E. (2003). Trends from the UNESCO Regional Consultation on Higher Education - A Concept Paper.

Jim Black (2005), «Branding of Higher Education», the Great Awakening in the Hallowed Halls of Academia Elizabeth Scarborough, President and Partner, May 2007.

Joseph, Mathew, and Deborah F Spake (2009) Summary Brief: University Branding Initiatives: What Do Private University

Students Want to Know about a Prospective Institution and How Do They Get Information? Society for Marketing Advance Proceedings, p.142.

Judson, K. M., Aurand, T. W., Gorchels, L., \& Gordon, G. L (2009). Building a University Brand from within: University Administrators" Perspectives of Internal Branding, Services Marketing Quarterly, 30 (1), (2009), 54-68

Kathleen Dawley (2000), «Successful Branding is Critical to Colleges and Universities Seeking to Prosper in Challenging Times», UK

Keller, K.L. (2003). Strategic Branding Management: Building, Measuring, and Managing Brand Equity, 8-9. Prentice Hall.

Kotler, P, \& Fox, K. F. A. (1995). Strategic Marketing for Education Institutions, (2nd Ed.). New Jersey: Prentice Hall.

Lockwood, R., \& Hadd, J. (2008). Building a Brand in Higher Education. Gallup Management Journal, 1-7.

Morrison, M. (2013) «Why Higher Education Needs Marketing More Than Ever». Advertising Age.

Riege, A., M (2003). Validity and Reliability Tests in Case Study Research: A Literature Review with Hands on Applications for

Each Research Phase. Qualitative Market Research - An International Journal, Vol.6, pp. 75-86.

Robert A. Sevier (2000), «Brand as Relevance», www.stamats.com/whitepapers.

Rony, M.E. and Rashid, S.M.A. (2009). «Perspective of Teaching-Learning Practices in Private Universities of Bangladesh» NAEM Journal, 5 (9), 67-77.

Rosenthal, G. (2003). A Name by any other Name: Responding to the Increasing Role of Marketing in Higher Education (Unpublished Doctoral Dissertation), University of Pennsylvania, Philadelphia.

Saunders, M., Lewis, P. \& Thornhill, A. (2007). Research Methods for Business Students, Harlow, UK, Pearson.

Scarborough, Elizabeth (2007). Branding the Higher Education: The Great Awakening in the Hallowed of Academia.

Schultz, D., E. \& Schultz, H., F. (2004). Brand Babble: Sense and Nonsense About Branding, London, Thomson.

Schultz, M., Hatch, M., J. \& Larsen, M. H. (2000). The Expressive Organization: Linking Identity, Reputation and the Corporate Brand. Oxford University Press.

Shamma, H., \& Hassan, S. (2009), Customer and Non-Customer Perspectives for Examining Corporate Reputation. Journal of

Product and Brand Management, 18(5), 326-337.

Shampeny, Renelle (2003), «Colleges Turn Attention to Branding in Competition for New Students», The Business Review

(Albany), Retrieved 5 June 2008 from [http://bizjournals.com/albany/stories/2003/10/27/ focus5.html? t=printable].

Simoes, C., Dibb, S. \& Fisk, R., P. (2005). Managing Corporate Identity: An Internal Perspective. Journal of the Academy of

Marketing Science, 33, 153-168 
M. I. Alam, M. O. Faruq, M. Z. Alam, M. O. Gani. Branding Initiatives in Higher Educational Institutions: Current Issues and Research Agenda

Stensaker, B. (2005). Strategy, Identity, and Branding - Re-Inventing Higher Education Institutions. A paper presented to the City Higher Education Seminar Series.

Wæraas, A. and Solbakk, M.N. (2009), Defining the Essence of a University: Lessons from Higher Education Branding. Higher Education $57,449-462$.

Why higher education needs marketing more than ever (2013) http://adage.com/article/cmo-strategy/higher-educationmarketing/244820/

«Higher Education and the Challenges of Communication». Noir Sur Blanc White Paper.

М. Ш. Алам, Даккський університет (Бангладеш);

M. О. Фарук, Університет Джаганнатх (Бангладеш);

M. 3. Алам, Ph.D., Університет підвищення кваліфікації (Бангладеш),

М. О. Гані, Університет Хіросіми (Японія), Університет підвищення кваліфікації (Бангладеш).

Брендинг закладів вищої світи: проблеми та перспективи

В основу статті покладено гіпотезу, що протягом останніх декількох років брендинг відіграє значну роль у діяльності не лише компаній, а й закладів вищої освіти (ЗВО). Зміна середовища, включаючи соціальні, правові та економічні умови, зумовлюе необхідність постійних змін у способах діяльності університету, що забезпечить ї функціонування в довгостроковій перспективі. У статті систематизовано та охарактеризовано сучасні концепції брендингу університетів Бангладеш державної та приватної форми власності, які сприяють їх популяризації. у рамках даного дослідження автори зазначають, що брендинг ЗВО Бангладеш $\epsilon$ складним процесом, що пояснюється його безсистемністю та розгалуженістю основних стейкхолдерів ЗВО. Об'єктом дослідження обрано десять провідних ЗВО Бангладеш різних форм власності. Базу даних для аналізу склали результати опитування 400 респондентів (200 студентів, які наразі навчаються та 200 потенційних студентів 3ВО). При цьому вибірку сформовано методом випадкового відбору. У статті визначено силу та статистичну значимість впливу семи змінних (імідж університету, якість освіти, рейтинг ЗВО, репутація, місце розташування, політична ситуація та якість підготовки викладачів) на суб'єктивну думку респондентів. Результати даного дослідження свідчать про наявність широкого спектру критеріїв, згідно яких студенти обирають між приватними та державними університетами Бангладеш. При цьому отримані результати засвідчили невідповідність вибору респондентами ЗВО для навчання та очікуваними особистісним критеріями відбору. Аналіз результатів опитування підтвердив гіпотезу, що студенти обирають університети за якістю освіти та рівнем популярності його бренду. Окрім цього, автори встановили, що роботодавці зацікавленні у рекрутингу випускників топ-брендових ЗВО з метою підвищення ефективності діяльності своїх компаній. У майбутньому отримані емпіричні результати дослідження можуть бути корисними для науковців та менеджменту $3 В 0$ державної та приватної форми власності.

Ключові слова: брендинг, заклади вищої освіти, маркетинг, Бангладеш, студент.

Manuscript received: 31.10 .2018

(c) The author(s) 2019. This article is published with open access at Sumy State University. 